\title{
Antecedents of Conspicuous Consumption, Status Aspiration, and Its Consequences: An Empirical Study on Migrant Blue-Collar Workers in GCC
}

\author{
Mathew Philip', Mimy Mathew², Gopalakrishnan Soundararajan³ \\ ${ }^{1}$ Department of Business and Accounting, Muscat College, Muscat, Sultanate of Oman \\ ${ }^{2}$ Faculty of Management, Law and Science, University of Bradford, Bradford, UK \\ ${ }^{3}$ Department of Business and Accounting, Muscat College, Ruwi, Sultanate of Oman \\ Email: mathew@muscatcollege.edu.om,mimy.mathew2000@gmail.com, soundararajan@muscatcollege.edu.om
}

How to cite this paper: Philip, M., Mathew, M., \& Soundararajan, G. (2021). Antecedents of Conspicuous Consumption, Status Aspiration, and Its Consequences: An Empirical Study on Migrant Blue-Collar Workers in GCC. Open Journal of Business and Management, 9, 731-751.

https://doi.org/10.4236/ojbm.2021.92038

Received: February 3, 2021

Accepted: March 20, 2021

Published: March 23, 2021

Copyright $\odot 2021$ by author(s) and Scientific Research Publishing Inc. This work is licensed under the Creative Commons Attribution International License (CC BY 4.0).

http://creativecommons.org/licenses/by/4.0/

\begin{abstract}
Conspicuous consumption means consumers prefer to buy expensive items to show their wealth and status to society. This study objective is to develop a framework that connects conspicuous consumption variables with the aspirations and consequences and to test the model among the migrant blue-collar workers located in the GCC countries. Primary data was collected with a structured questionnaire from 400 blue-collar migrant workers in GCC countries. Eight hypotheses were formed and tested by using factor analysis and structural equation model analysis. The study concluded that blue-collar expatriate workers exhibit a high level of lush luxury behavior to gain family and social acceptance, which is one of the best ways of expressing themselves; however these are attained at the cost of financial sustainability of personal wellbeing.
\end{abstract}

Keywords

Conspicuous Consumption, Antecedents, Consequences, Blue-Collar

\section{Introduction}

Conspicuous consumption theory was coined by Veblen, accordingly, people consume luxury items to signal their wealth and social status (Veblen, 1899). Simmel also supported this view as people who would like to ascend in social status always emulate the consumption pattern of the upper class (Simmel, 1957). Conspicuous consumption traditionally has been observed as a behavior 
of the wealthy and upper class for showcasing their social status; however (Charles et al., 2009) observed that those in the lower classes are also engaged in conspicuous consumption. Researchers noted that people with low income have higher aspirations for conspicuous consumptions (Srivastava et al., 2020) and they are willing to sacrifice their basic needs for status consumptions (Joncourt et al., 2019), which also highlights the financial side. Therefore, a refined view has been added to the field of study as individuals of all classes are aspirants in gaining social status, which means consumers who care about social status are involved in conspicuous consumption. This behavior is quite different from the frequently purchased goods consumed for basic needs. Van Boven (2005) found that conspicuous consumption is more of an experience of consumers rather than mere material products in the modern context. Another trend of modern consumers is to associate their personality with luxury brands rather than just looking for status (Bronner \& De Hoog, 2018). So, conspicuous consumers merely do not buy only materials but also care more about symbolic meaning and values associated with the brands. Consumers of today seek life experience instead of possessing expensive goods, for example, consumers would like to spend on vacations and events rather than possessing expensive jewelry (Pine \& Gilmore, 2013). Additionally, several scholars have given various perspectives and applications in modern brand management (Jhamb et al., 2020). The motives of purchasing counterfeits (Quach \& Thaichon, 2018) and second hands (Cervellon et al., 2012) of prominent luxury brands for signaling status are also noted as consequences of conspicuous consumption.

This study has adopted a new framework that links the variables of antecedents of conspicuous consumption, aspirations for status, and its positive and negative consequences, also applied to a new setting of migrant blue-collar workers. The construct used for this study has not been tested empirically by any other previous studies to our best knowledge.

The backdrop of this study has been taken from the migrant blue-collar workers located in the GCC (Gulf Cooperative Council). The six GCC countries have employed many expatriates in various sectors of their economies, and most of them are blue-collar workers. As per the national statistics published by these countries, the majority of the blue-collar workers come from India, Bangladesh, Pakistan, the Philippines, and Egypt, etc. They work predominantly in sectors like construction, maintenance, cleaning, and other technical and non-technical areas. Their wages are relatively lower; however exhibit aspirations of providing a better standard of living for their family in their natives, to whom they visit once in two years or less. During such visits they spend most of their saved income and some may take even loans to show a luxury lifestyle. This study is going to test whether it is the real case among the expatriate blue-collar workers.

The outcome of this study could be used in a wider context of migrant workers and the blue-collar workers of underdeveloped nations.

The research questions 
RQ1: Do blue-collar expatriate workers have a higher aspiration for status consumption?

RQ2: How the antecedents of conspicuous consumption do affect the aspirations of blue-collar expatriate workers?

RQ3: What are the positive consequences of status consumption for blue-collar expatriate workers?

RQ4: What are the negative consequences of status consumption for blue-collar expatriate workers?

This study has implications for governmental, non-governmental, and business organizations to formulate policies and strategies that protect expatriate workers from the negative elements of conspicuous consumption, apart from contributing knowledge to the field of study. This paper chaptered with literature review and hypothesis of various aspects of antecedents Conspicuous Consumption, Aspiration for Status Consumption among Low-Income People and Consequences of Conspicuous Consumption, Theoretical Framework of the Study, research methodology for the study and analyzed variables using with percentage analysis, KMO and Bartlette's test, factor analysis, reliability test and structural equation model.

\section{Literature Review \& Research Hypotheses}

\subsection{Antecedents Conspicuous Consumption}

The term conspicuous consumption is multidisciplinary and is very popular in day to day life. More than 100 years ago Veblen (1899) wrote this concept in "The Theory of the Leisure Class" if according to exogenous preference an individual maximizes the utility and the involvement of social factors. He argues that "wealthy individuals often consume highly conspicuous goods and services to show their wealth, thereby achieving higher social status". So, this concept was initially considered as something only wealthy people could achieve. Simmel (1957) defended this idea by saying that individuals who would like to rise in social status emulate the consumption behavior of the upper class. Kahle et al. (2003) mentioned that consumers buy luxury goods not only for the material needs but also for their social needs as status. Further Amaldoss \& Jain (2005) viewed that it is not only the rich class but also the middle class and working class that aspires for prestige and status. This aspiration of the lower class has been further validated by researchers through their studies (Kapeller \& Schuetz, 2015; Srivastava et al., 2020; Kistruck et al., 2013). Social signaling is an important condition for conspicuous condition; however, the power is not the same for all categories (Perez-Truglia, 2013). A study conducted by Kamakura \& Du (2012), identified the goods that have higher signaling ability-for example houses and cars. Mumel \& Snoj (1999) carried out a study for the visibility of 43 products, and then ranked differently. Further, it was noticed that products that have public consumption need visibility which is a precondition (Heffetz, 2012), and they want their reference group to see or know their consumer behavior. Here 
we can find two types of consumptions: 1) consumption which can be seen directly by others 2) indirectly visible to others; the importance of visibility as a vital aspect of conspicuous consumption and individuals want to show off the same to others. Another aspect of auto signaling, which means individuals consume luxurious products for attaining a self-feeling of achievement, success, and pleasure (Lai et al., 2019), is a matter of self-image. From the literature survey, it has been noticed that several multidisciplinary studies in the field of conspicuous consumption from the viewpoints of economics, marketing, sociology, psychology, and change in definitions are presented up to date (Byrom \& Deringer, 2020; Goenka \& Thomas, 2020; Jeong \& Jeon, 2020; Klabi, 2020).

From the above reviews, it is quite clear that individuals want to increase their prestige before society by consuming conspicuously, which means their possession communicates social status. This type of consumer behavior has been observed in all classes of society, including among the poor who engage in this type of behavior even before meeting their basic needs (Kapferer \& Michaut-Denizeau, 2014; Belk et al., 1989). Here we would be considering three important dimensions that trigger the aspirations for conspicuous consumption (Kwon, 2020; Neave et al., 2020; Qattan \& Al Khasawneh, 2020; Verdugo \& Ponce, 2020).

1) Consumptions in public context through luxury products and services to impress the reference group. Researchers observed this as ostentation and signaling, and it influences status consumption (Shukla, 2010; Amaldoss \& Jain, 2005; Bagwell \& Bernheim, 1996; Sørensen \& Hjalager, 2020; Keinan et al., 2019; Oe et al., 2018; Zhao et al., 2017).

2) Ownership of rare products which many others do not possess, called uniqueness which help consumers to establish status consumption (Corneo \& Jeanne, 1998; Latter et al., 2010; Blazquez et al., 2020; Greenberg et al., 2020; Nabi et al., 2019a; Nabi et al., 2019b; Shaikh, 2019).

3) The symbolic value that has been shared by the luxury brands, which either meet or surpass the expectation of the reference group is known as social conformity. This leads to social visibility and status (Wong \& Ahuvia, 1998; Mann \& Sahni, 2015; Amalia et al., 2019; Diallo et al., 2020; Kim et al., 2019; Mostafa, 2019; Tofighi et al., 2020; Wang \& Qiao, 2020).

The relationship between the above variables and status consumption has already been identified by several types of research in different contexts and cultures, so this wider perspective is taken into consideration while designing the model for this study (Mann \& Sahni, 2015; Assimos et al., 2019; Arthur et al., 2020; Assimos et al., 2019; Yarimoglu \& Binboga, 2019).

These propose the following three hypotheses and it has verified through factor analysis.

H01: Increase in Ostentation and Signaling (OS) leads to higher Aspiration for Social Consumption (ASC)

H02: Increase in Uniqueness (UNI) leads to higher Aspiration for Social Consumption (ASC)

H03: Increase in Social Conformity (SC) leads to higher Aspiration for Social 
Consumption (ASC)

\subsection{Aspiration for Status Consumption among Low-Income People}

Researchers from various disciplines such as sociology, psychology, and economics reveal that people with low financial background engage in conspicuous consumptions to overcome the feeling of deprivation, Sen (1983); Eckhardt et al. (2015); Jaikumar et al. (2018); Basu (2008) observed that there is a lack of high return financial institutions in emerging economies like India and Brazil. Due to this people may not involve their status savings but rather indulge in conspicuous consumption (Jaikumar \& Sarin, 2015; Corneo \& Jeanne, 1999). This shows that low-income individuals want to improve their subjective social status by indulging in conspicuous consumption. Conspicuous consumption among low-income people has been reported in many studies, for example (Grossman, 2011; Linssen et al., 2011; Bryant \& Hill, 2019; Singh \& Trott, 2019; Sokolov \& Sokolova, 2019; Srivastava et al., 2020).

There are many concepts and models to elaborate the aspirational consumption tendencies of low-income individuals, which leads to compensatory theory. Using this theory Subrahmanyan \& Gomez-Arias (2008) explained the lush wedding behavior, Jaikumar et al. (2018) discussed jewelry and ornaments, and Subrahmanyan \& Gomez-Arias (2008) about durable electronics. It shows that poor individuals with low self-esteem consume status products and compare themselves with the rich class, also called the trickle-down effect (Colson-Sihra \& Bellet, 2018; Olukoju, 2018; Piotrowska, 2017; Tade \& Nnamani, 2017). In the context of the study, the blue-collar expatriate workers' incomes are not directly visible to others, but family and society normally believe that they earn heavily due to their foreign job. This mounts pressure on them to congruent with the beliefs of family and friends so the option to live with this is to indulge in conspicuous consumption, leading to higher aspirations for status consumption. But in reality, the income is low, and many are not able to afford it, and their subjective economic wellbeing is higher because they don't want to lose their face against their social belief which has been provided by various researches conducted in different cultures and context (Wai \& Osman, 2019; Bricker et al., 2020; Matos, 2019; Tarola \& Zanaj, 2019).

\subsection{Consequences of Conspicuous Consumption}

This may have positive and negative consequences for poor individuals. Rucker \& Galinsky (2009); Jaikumar \& Sarin (2015) observed that conspicuous consumption enhances social status due to which their confidence, happiness and satisfaction will increase out of their poor life. This could be regarded as a positive effect of status consumption. However, this will affect their long term living standard as they must cut down on their basic needs such as food, education, and health. Cannon \& Rucker (2019); Chakravarti (2006) indicated that long-term 
status consumption will put them into debt and poverty. Unfortunately, such aspiration for conspicuous consumption negatively impacts their long-term financial sustainability and their areas of priority (Matos, 2019, Kaufman, 2018). Studies conducted by Mullainathan (2012); Goldsmith \& Clark (2012) reveal that prolonged deprivation of materialistic consumption crushes self-control of the household and future orientation. Secondly, low-income people indulge in consuming used products to satisfy their subjective social status. Secondhand purchase is the purchase of a used product that is functional, already used by a previous owner (Kessous \& Valette-Florence, 2019; Turunen \& Leipämaa-Leskinen, 2015; Cervellon et al., 2012; Ochkovskaya, 2016; Turunen \& Poyry, 2019). This behavior has two sides: 1) it satisfies the brand aspiration (Truong et al., 2010); 2) fits within the financial constraints (Guiot \& Roux, 2010; Roux \& Guiot, 2008). Thirdly, such individuals resort to counterfeit products, Chaudhry \& Stumpf (2011); Bian et al. (2015); Huh (2014); Srisomthavil \& Assarut (2018); Wiedmann et al. (2012) observed this as one of the means for status. Counterfeit products are illegal products that duplicate the uniqueness of an original brand. Liberman et al. (2011); Poddar et al. (2012); Furnham \& Valgeirsson (2007) noted that these products are dangerous to the economy, sold in the black market and threaten the patents and copyrights of the original brand.

The positive and negative consequences reviewed above, hypotheses the following:

H04: Increase in aspiration for social consumption (ASC) leads to higher self-expression (SE)

H05: Increase in aspiration for social consumption (ASC) leads to the financial burden (FB)

H06: Increase in aspiration for social consumption (ASC) leads to second-hand buying (SB)

H07: Increase in aspiration for social consumption (ASC) leads to counterfeit buying (CB)

H08: Increase in aspiration for social consumption (ASC) leads to compromising the budget and basic needs (CBB)

The above hypotheses are verified by using Structured Equation Model analysis (SEM).

\subsection{Theoretical Framework of the Study}

Figure 1 shows the theoretical framework for the study related to Aspiration for Status Consumption and Consequences Model.

\section{Research Methodology}

\subsection{Sampling}

For the study, the primary data was collected with a self-designed structured questionnaire based on various reviews of literature and expert discussion. Samples 


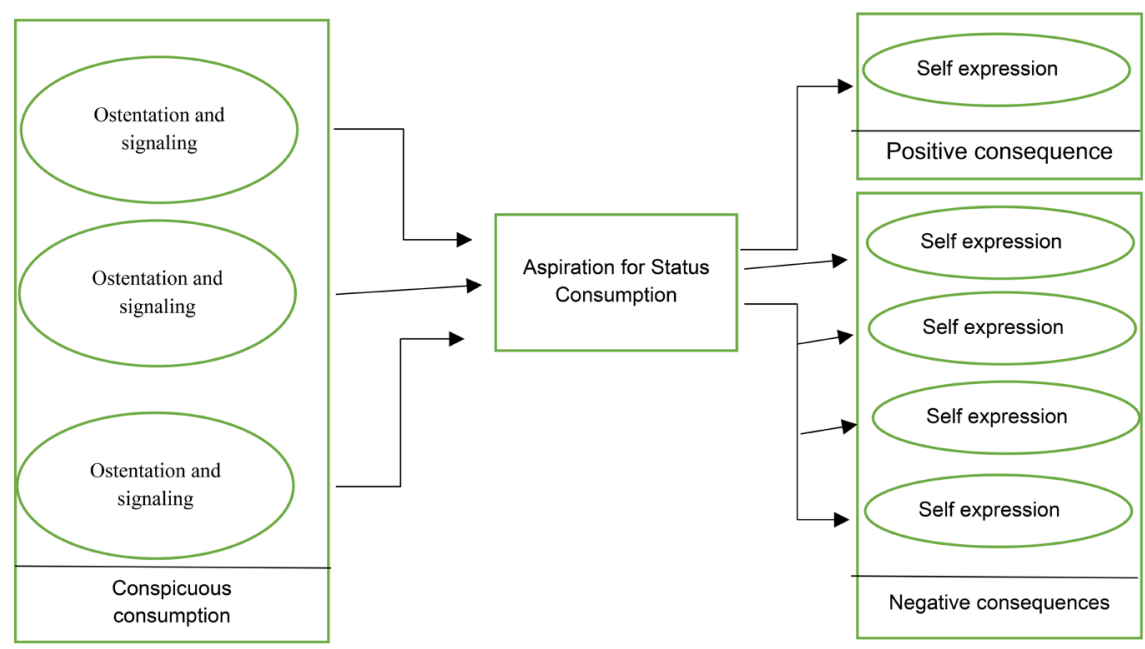

Figure 1. Aspiration for status consumption and consequences model.

were drawn from the GCC blue-collar migrant workers. Sample size for the study is 383 respondents which has based on $95 \%$ confidence level, $5 \%$ marginal error, $70 \%$ estimated response.

\subsection{Structure of the Questionnaire and Scales}

Section-1: Demographic variables (Age, Nationality, Gender, Monthly Average Income, Marital Status, and Frequency of Annual Leave)

Section-2: Statements that measure the variables (on a 7-point Likert scale; 1-Highly Disagree to 7-Highly Agree)

1) When you were considering a brand:

Ostentation and signaling-(OS)

- I preferred to buy luxury brands

- I was ready to pay more for a luxury brand

- I was attracted to luxury brands

Uniqueness-(UNI)

- I wanted to communicate that I am unique

- I wanted to attach my personality with the brand name

- I wanted to create a distinctive personal image

Social Conformity-(SC)

- I wanted others to accept me

- I wanted to create an impression on other people

- I wanted others to appreciate me

2) When I am in my hometown:

Aspiration for Status Consumption-(ASC)

- I had a high aspiration for a status symbol

- I wanted everyone to know that I work abroad

- I wanted to show everyone that I am a successful individual

3) Luxury brands give the feeling of: 
Self-Expression-(SE)

- Socially accepted

- Distinctive from others

- Acceptance of working abroad

4) After returning from your hometown:

Compromise on budget and basic needs-(CBB)

- I really must save a lot of money now, for that, I compromise my basic needs like food, accommodation, and health care

- I hardly spend money on my clothing and entertainment needs

- I feel it is better to save money now for the sake of a good and luxurious family life

5) I have financial liabilities due to my previous luxurious consumptions:

Financial Burden-(FB)

- I had to take financial loans

- A good portion of my income is now going for repayment of loans

- I am anxious about my financial stability

6) Purchase of counterfeits of brands.

Counterfeiting-(CB)

- Due to inadequate finance, I had purchased a few counterfeits of brands to show conspicuous consumption

- I knew these products are illegal, however, it helped me to get the image of luxurious consumption for a shorter period

7) Purchase of used products of the original brands

Second-hand buying-(SB)

- Due to inadequate finance, I had purchased a few second hands of brands to show conspicuous consumption

- Second-hand buying helped me to get the image of the luxury brand

\subsection{Pilot Study}

Pretesting of the questionnaire was conducted before administering the same to the respondents. A sample size of 30 was used for the pretesting and their feedback was used for the refinement of the questionnaire.

\section{Analysis}

\subsection{The Characteristics of the Respondents}

Table 1 shows democratic characteristics of the study respondents

\subsection{KMO and Bartlette's Test}

Table 2 shows KMO and Bartlette's test provided the suitability of data for factor analysis.

The sampling adequacy value of .826 (high value close to 1.0) and high level of significance $(.000<.005)$ indicate that the factor analysis for this data is very 
useful.

\subsection{Factor Analysis}

A factor analysis was carried out to find out whether the items used in this research model discern each other.

Table 1. The characteristics of the respondents.

\begin{tabular}{|c|c|c|}
\hline Characteristics & Frequency & Inference \\
\hline Gender & $\begin{array}{c}\text { Male: } 73 \% \\
\text { Female: } 27 \%\end{array}$ & $\begin{array}{l}\text { The majority are } \\
\text { male workers }(73 \%)\end{array}$ \\
\hline Nationality & $\begin{array}{c}\text { Indians: } 29 \% \\
\text { Pakistanis: } 20 \% \\
\text { Bangladeshis: } 26 \% \\
\text { Egyptians: } 11 \% \\
\text { Others: } 14 \%\end{array}$ & $\begin{array}{l}\text { Most of the respondents } \\
\text { are from India, Pakistan, } \\
\text { and Bangladesh }(75 \%)\end{array}$ \\
\hline Age & $\begin{array}{c}21-29: 3 \% \\
30-39: 29 \% \\
40-49: 39 \% \\
50-59: 28 \% \\
60 \geq: 1 \%\end{array}$ & $\begin{array}{l}\text { The majority of the respondents } \\
\text { are aged between } 30 \text { to } 59 \text { years } \\
\text { of age }(96 \%)\end{array}$ \\
\hline Monthly Income (USD) & $\begin{array}{c}\leq 300: 2 \% \\
300-399: 8 \% \\
400 \text { - } 499: 11 \% \\
500 \text { - 599: } 22 \% \\
600 \text { - 699: } 26 \% \\
700 \text { - 799: } 21 \% \\
800 \text { - } 899: 7 \% \\
900-999: 3 \% \\
1000 \geq 0 \%\end{array}$ & $\begin{array}{l}\text { Majority of the respondents } \\
\text { having an income range } \\
\text { between } 500 \text { to } 799 \text { USD (69\%) }\end{array}$ \\
\hline Marital Status & $\begin{array}{c}\text { Married: } 72 \% \\
\text { Unmarried: } 27 \% \\
\text { Widower-Widow/Divorced: } 1 \%\end{array}$ & $\begin{array}{l}\text { Most of the respondents } \\
\text { are married }(72 \%)\end{array}$ \\
\hline $\begin{array}{l}\text { Frequency of the Annual } \\
\text { Leave }\end{array}$ & $\begin{array}{c}\geq \text { Twice in a year: } 0 \% \\
\text { Once in a year: } 31 \% \\
\text { Once in two years: } 66 \% \\
\leq \text { Once in three years: } 3 \%\end{array}$ & $\begin{array}{c}\text { Most of the respondents } \\
\text { used to visit their native } \\
\text { home once in two years (66\%) }\end{array}$ \\
\hline
\end{tabular}

Table 2. KMO and Bartlette's test.

\begin{tabular}{lcc}
\hline Kaiser-Meyer-Olkin Measure of Sampling Adequacy & .826 \\
\hline & Approx. Chi-Square & 4681.157 \\
Bartlett's Test of Sphericity & $\mathrm{df}$ & 98 \\
& Sig. & .000 \\
\hline
\end{tabular}


Table 3 interprets that the percentage of variance, the total variance accounting for each factor explains the level of variance. Here it is $97 \%$ which is at an acceptable level. Eigenvalues determine the factors of values to be retained (greater than 1 as per Kaiser criteria to be retained). The eigenvalue for the item CBB is only .925, therefore this variable has been deleted from the study model. The three variables OS, UNI, and SC have high eigenvalues $(4.425,3.902$, and 3.720 respectively), which go in congruence with the literature survey of this study. For the consequence variables, the eigenvalues are validating the model fit for SE (2.961), FB (2.441), CB (1.836), SB (1.389); all agree with the previous studies. From the factor analysis, the item CBB doesn't fit in the model of this study although it was cited in the previous studies, therefore it has been decided to eliminate hypothesis (H08) from this study and the framework was updated accordingly. Figure 2 shows the revised Aspiration for Status Consumption and Consequences Model.

Table 3. Factor analysis.

\begin{tabular}{|c|c|c|c|c|}
\hline Factor & Items & $\begin{array}{l}\text { Factor } \\
\text { Loading }\end{array}$ & $\begin{array}{l}\text { Eigen } \\
\text { Value }\end{array}$ & $\begin{array}{c}\text { Variance } \\
\text { Explained (\%) }\end{array}$ \\
\hline OS & $\begin{array}{l}\text { I preferred to buy luxury brands } \\
\text { I was ready to pay more for luxury brand } \\
\text { I was attracted to luxury brands }\end{array}$ & $\begin{array}{l}.850 \\
.761 \\
.751\end{array}$ & 4.425 & 18.269 \\
\hline UNI & $\begin{array}{l}\text { I wanted to communicate that I am unique } \\
\text { I wanted to attach my personality with the brand name } \\
\text { I wanted to create a distinctive personal image }\end{array}$ & $\begin{array}{l}.735 \\
.619 \\
.898\end{array}$ & 3.902 & 16.950 \\
\hline SC & $\begin{array}{l}\text { I wanted others to accept me } \\
\text { I wanted to create an impression on other people } \\
\text { It wanted others to appreciate me }\end{array}$ & $\begin{array}{l}.765 \\
.711 \\
.641\end{array}$ & 3.720 & 15.890 \\
\hline ASC & $\begin{array}{l}\text { I had a high aspiration for a status symbol } \\
\text { I wanted everyone to know that I work abroad } \\
\text { I wanted to show everyone that I am a successful individual }\end{array}$ & $\begin{array}{l}.693 \\
.835 \\
.769\end{array}$ & 3.401 & 11.965 \\
\hline SE & $\begin{array}{l}\text { Socially accepted } \\
\text { Distinctive from others } \\
\text { Acceptance of working abroad }\end{array}$ & $\begin{array}{l}.589 \\
.817 \\
.775\end{array}$ & 2.961 & 11.591 \\
\hline FB & $\begin{array}{l}\text { I had to take financial loans } \\
\text { A good portion of my income is now going for repayment of loans } \\
\text { I am anxious about my financial stability }\end{array}$ & $\begin{array}{l}.867 \\
.589 \\
.643\end{array}$ & 2.441 & 9.181 \\
\hline $\mathrm{CB}$ & $\begin{array}{l}\text { Due to inadequate finance, I had purchased a few counterfeits of brands to show } \\
\text { conspicuous consumption } \\
\text { I knew these products are illegal, however, it helped me to get the image of } \\
\text { luxurious consumption for a shorter period }\end{array}$ & $\begin{array}{l}.671 \\
.593\end{array}$ & 1.836 & 7.034 \\
\hline SB & $\begin{array}{l}\text { Due to inadequate finance, I had purchased a few second hands of brands to show } \\
\text { conspicuous consumption } \\
\text { Second-hand buying helped me to get the image of the luxury brand }\end{array}$ & $\begin{array}{l}.599 \\
.697\end{array}$ & 1.389 & 6.120 \\
\hline $\mathrm{CBB}$ & $\begin{array}{l}\text { I really must save a lot of money now, for that, I compromise my basic needs like } \\
\text { food, accommodation, and health care } \\
\text { I hardly spend money on my clothing and entertainment needs } \\
\text { I feel it is better to save money now for the sake of a good and luxurious family life }\end{array}$ & $\begin{array}{l}.315 \\
.487 \\
.467\end{array}$ & .925 & 3.000 \\
\hline
\end{tabular}




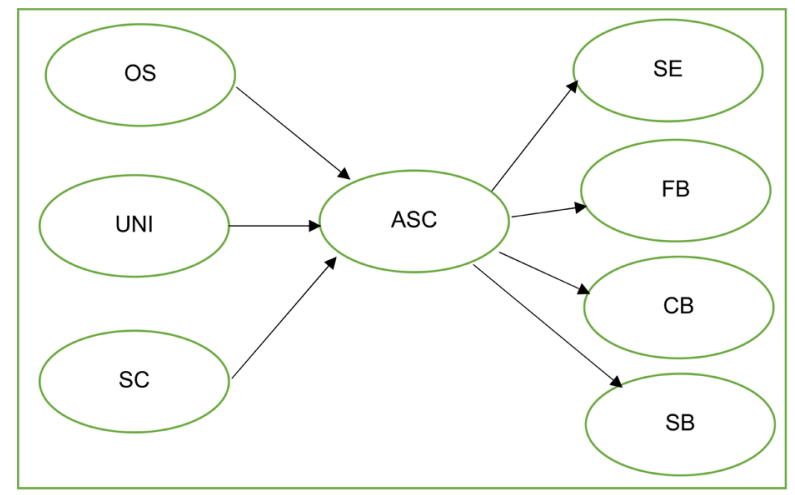

Figure 2. Revised aspiration for status consumption and consequences model.

\subsection{Reliability Test}

To measure the internal consistency and scale reliability Cronbach's alpha has been used for the test.

Table 4 interprets that Cronbach Alpha Coefficient is .832 for the 25 items hence it is indicating that this study has a high internal consistency and reliability.

\subsection{Structural Equation Model}

In the structural equation model, the goodness of fit (GoF) is 62.3\%, which is appropriate for this study. The bootstrapping intervals agree with $\mathrm{p}$ values, except for the variable counterfeiting.

Table 5 and Figure 3 show that ASC constructs, $\beta$ values for the independent variables OS, UNI, and SC are $.38, .23$ and .29 respectively; all these are statistically significant with $\mathrm{p}$ values less than .005 . Therefore, the higher the values of the independent variables, the higher the ASC. It has also explained the high effect size of the regression value (82.6\%). These indicate an important theoretical finding as migrant blue-collar workers exhibit higher aspirations for social status.

Secondly, it has noted that higher ASC leads to greater SE ( $\beta=.77, p$-value $=.000$ and regression $=72.2 \%$ ). This is a lush behaviour of the migrant workers to indulge in luxuries, one of the ways of gaining respect and appreciation from their community and family.

Thirdly, the relationship between ASC and FB gives a significant positive high relationship $(\beta=.49, p$-value $=.032$ and regression $=47.3 \%)$. This visceral behavior of the workers often leads them into financial traps that have a physiological and psychological impact on their wellbeing.

Fourthly, this study did not establish a significant relationship between CB and ASC, which comes against the previous studies. The reason would be 1) Expected income from abroad 2) Fear of family and friends as it will work against them over time. This needs further validation through future studies.

Finally, there is only a moderate influence over SB $(\beta=.11, p$-value $=.042$ and regression $=17.4 \%$, which pointed out that there is no high affinity towards SB. 
The secondhand option varies according to the categories of goods. A detailed study is recommended to investigate this further.

Table 6 shows the result of framed hypotheses. Out of 7 hypotheses, 6 are accepted and 1 hypothesis is rejected. It is interpreted that increase in OS leads to higher ASC, Increase in UNI leads to higher ASC, Increase in SC leads to higher ASC, Increase in ASC leads to higher SE, Increase in ASC leads to FB and Increase in ASC leads to SB however there is evidence on ASC leads to CB.

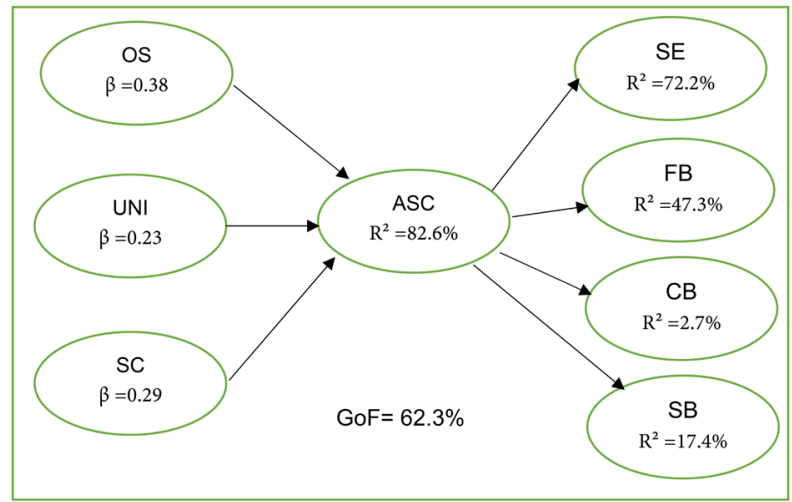

Figure 3. Structural equation diagram.

Table 4. Reliability statistics.

\begin{tabular}{ccc}
\hline Cronbach's Alpha & Cronbach's Alpha Based on Standardized Items & N of Items \\
\hline .832 & .798 & 25 \\
\hline
\end{tabular}

Table 5. SEM model analysis.

\begin{tabular}{cccccc}
\hline Endogenous & Exogenous & $\beta$ & Bootstrapping Interval (95\%) & $p$-Value & $\mathrm{R}^{2}$ \\
\hline \multirow{2}{*}{ ASC } & OS & .38 & {$[.19 ; .63]$} & .017 & \\
& UNI & .23 & {$[.09 ; .39]$} & .011 & $82.6 \%$ \\
& SC & .29 & {$[.12 ; .54]$} & .004 & \\
SE & ASC & .77 & {$[.66 ; .88]$} & .000 & $72.2 \%$ \\
FB & ASC & .49 & {$[.40 ; .59]$} & .032 & $47.3 \%$ \\
CB & ASC & .04 & {$[-.01 ; .11]$} & .197 & $2.7 \%$ \\
SB & ASC & .11 & {$[.00 ; .22]$} & .042 & $17.4 \%$ \\
\hline
\end{tabular}

Table 6. Testing of hypotheses.

\begin{tabular}{ccc}
\hline & Hypothesis & Result \\
\hline H01 & Increase in OS leads to higher ASC & Accepted \\
H02 & Increase in UNI leads to higher ASC & Accepted \\
H03 & Increase in SC leads to higher ASC & Accepted \\
H04 & Increase in ASC leads to higher SE & Accepted \\
H05 & Increase in ASC leads to FB & Accepted \\
H06 & Increase in ASC leads to SB & Accepted \\
H07 & Increase in ASC leads to CB & Rejected \\
\hline
\end{tabular}




\section{Conclusion}

This study has extended the dimensions of the previous research. From the earlier studies it was noted that individuals engage in conspicuous consumption despite social class, and it was tested in different contexts and cultures already. However, this study has adopted a different approach to link conspicuous consumption, aspirations, and consequences. Towards this endeavor, this study attempted two things: 1) developing a framework with significant variables, 2) empirically testing the model within the context of migrant workers. While developing the framework it is noted that the three dimensions: ostentation and signaling, uniqueness, and social conformity have higher attributions to trigger the aspirations which engage them in conspicuous consumption. This goes in agreement with the literature review and fits with the previous models. Extending this to a consequence level, this model developed two sets of criteria that affect the positive and negative aspects. This model has been validated with factor analysis so it could be applied in various contexts in the future. The skeleton model explored more on the physiological and psychological aspects of workers, and it could be developed further by adding more variables related to business environmental aspects. This model could not establish a model fit with the variable that deals with a compromise on the budget and basic needs. We have different takes on this finding 1) in the context of study workers were provided with accommodation, food and medical insurance by the sponsored companies which are mandatory as per the laws of the GCC countries; 2) the measurement scale should need more specific psychological variables to measure these accurately. These have shown the limitations of this study.

From the empirical evidence, it has been observed that the migrant workers exhibit higher aspirations for conspicuous consumption. This has many psychological aspects as noted in the finding of this study: 1) workers believe that they can compensate for their status and absence of being away from their hometown through conspicuous consumption; 2) they want to show off that they are successful individuals since they are working abroad; 3) their society views them only through lifestyle and has no visibility on their working conditions; 4 ) it is a sort of relief from their hard-working conditions and lonely living environment. The study reveals the lush luxury behavior of the workers which has positive and negative consequences. Self-expression is considered as one of the most important psychological needs for the workers while in their hometown. They are ready to sacrifice anything to gain this, and it is an important insight as the power of self-expression seems to be one of the most prominent among human needs. On the contrary, the negative consequences are having a bigger impact on their wellbeing. A tradeoff between self-expression and finance is important, unfortunately, society and businesses do not consider this as important. We believe the modern business should also include this under their responsibilities including the financial wellbeing of consumers along with the extrinsic values of 
the brand.

One of the important observations from this study is that the migrant workers do not attach much attribution towards counterfeit brands. We believe it has some underpinning reasons: 1) the availability of easy finance options; 2) counterfeits don't go in tandem with the belief of the expatriate workers; 3 ) involvement of family and friends in the buying process while workers are in their hometown. This is regarded as a positive move although there are other negative financial implications. Another observation is about secondhand buying behavior. It seems the secondhand buying behavior should not be viewed through a single lens. This should go into detail with specific categories and market conditions. For example, a secondhand car market will be very much encouraging if it provides greater values and tax benefits. This study did not consider this element, so it remains as another limitation of this study.

In summary, conspicuous consumption behavior is profound among the migrant workers and they are ready to take any risk although they are working in hard labor, unstable jobs and financial situations. While preparing this research COVID-19 has already battered the economy of the GCC nations due to lockdown and social distancing, nevertheless these elements could not be considered as the survey part has been completed before this period. There has been a mass exodus of migrant workers due to job loss and unpaid salaries. This would impact the workers; however, the framework of this study has greater relevance to test their conditions during and after COVID-19. The reason to state this is that during this study, the migrant workers had already been to adverse working conditions due to nationalization policies, economic disruptions, and regional politics. So, there was already a scenario of instability prevailing in the migrant conditions, even though they thrive towards conspicuous consumption is quite evident. Conceding these, we believe this research has a long-lasting impact and could be applied in any culture or context.

\section{Future Research Direction}

Future research direction includes:

1) The model of this research needs further development by including other variables of sustainable conspicuous consumption.

2) The consumer behavior of migrant workers towards counterfeits of brands needs further investigation.

3) Secondhand buying behavior of migrant workers would be investigated specifically according to their categories.

\section{Acknowledgements}

The authors would like to acknowledge the support received from Manjima, Khalid, Riham, Ibrahim and Hussain for supporting the data collection (questionnaires) from the GCC nations. 


\section{Conflicts of Interest}

The authors declare no conflicts of interest regarding the publication of this paper.

\section{References}

Amaldoss, W., \& Jain, S. (2005). Conspicuous Consumption and Sophisticated Thinking. Management Science, 51, 1449-1466. https://doi.org/10.1287/mnsc.1050.0399

Amalia, K. A., Vita, P., \& Rahman, F. (2019). Values as Drivers of Luxury Brand Consumption for Young MAC Consumers. Pertanika Journal of Social Sciences \& Humanities, 27, 2313-2332.

Arthur, D., Sherman, C. E., Al Hameli, N. S., \& Al Marzooqi, S. Y. (2020). Materialism in the United Arab Emirates: A Grounded Model of Materialism in an Emerging Market. International Journal of Emerging Markets, 15, 507-533. https://doi.org/10.1108/IJOEM-08-2017-0277

Assimos, B. M., Pinto, M. D. R., Leite, R. S., \& de Andrade, M. L. (2019). Conspicuous Consumption and Its Relation to Brand Consciousness, Status Consumption and Self-Expression. Brazilian Business Review, 16, 350-368.

Bagwell, L. S., \& Bernheim, B. D. (1996). Veblen Effects in a Theory of Conspicuous Consumption. American Economic Review, 86, 349-373.

Basu, K. (2008). The Enigma of India. Journal of Economic Literature, 46, 396-406. https://doi.org/10.1257/jel.46.2.396

Belk, R. W., Wallendorf, M., \& Sherry Jr., J. F. (1989) The Sacred and the Profane in Consumer Behavior: Theodicy on the Odyssey. Journal of Consumer Research, 16, 1-38. https://doi.org/10.1086/209191

Bian, X., Haque, S., \& Smith, A. (2015). Social Power, Product Conspicuousness, and the Demand for Luxury Brand Counterfeit Products. British Journal of Social Psychology, 54, 37-54. https://doi.org/10.1111/bjso.12073

Blazquez, M., Alexander, B., \& Fung, K. (2020). Exploring Millennial's Perceptions towards Luxury Fashion Wearable Technology. Journal of Fashion Marketing and Management, 24, 343-359. https://doi.org/10.1108/JFMM-09-2019-0200

Bricker, J., Krimmel, J., \& Ramcharan, R. (2020). Signaling Status: The Impact of Relative Income on Household Consumption and Financial Decisions. Management Science, in press. https://doi.org/10.1287/mnsc.2019.3577

Bronner, F., \& De Hoog, R. (2018). Conspicuous Consumption and the Rising Importance of Experiential Purchases. International Journal of Market Research, 60, 88-103. https://doi.org/10.1177/1470785317744667

Bryant, A., \& Hill, R. P. (2019). Poverty, Consumption, and Counterintuitive Behavior. Marketing Letters, 30, 233-243. https://doi.org/10.1007/s11002-019-09494-8

Byrom, B., \& Deringer, S. A. (2020). Conspicuous Consumption in Outdoor Recreation: A Pilot Study. Journal of Outdoor Recreation Education and Leadership, 12, 264-266. https://doi.org/10.18666/JOREL-2020-V12-I2-9879

Cannon, C., \& Rucker, D. D. (2019). The Dark Side of luxury: Social Costs of Luxury Consumption. Personality and Social Psychology Bulletin, 45, 767-779. https://doi.org/10.1177/0146167218796790

Cervellon, M.-C., Carey, L., \& Harms, T. (2012). Something Old, Something Used: Determinants of Women's Purchase of Vintage Fashion vs Second-Hand Fashion. Inter- 
national Journal of Retail \& Distribution Management, 40, 956-974.

https://doi.org/10.1108/09590551211274946

Chakravarti, D. (2006). Voices Unheard: The Psychology of Consumption in Poverty and Development. Journal of Consumer Psychology, 16, 363-376.

https://doi.org/10.1207/s15327663jcp1604_8

Charles, K. K., Hurst, E., \& Roussanov, N. (2009). Conspicuous Consumption and Race. Quarterly Journal of Economics, 124, 425-467. https://doi.org/10.1162/qjec.2009.124.2.425

Chaudhry, P. E., \& Stumpf, S. A. (2011). Consumer Complicity with Counterfeit Products. Journal of Consumer Marketing, 28, 139-151. https://doi.org/10.1108/07363761111115980

Colson-Sihra, E., \& Bellet, C. (2018). The Conspicuous Consumption of the Poor: Forgoing Calories for Aspirational Goods. SSRN Electronic Journal. https://doi.org/10.2139/ssrn.3270814

Corneo, G., \& Jeanne, O. (1998). Social Organization, Status, and Savings Behavior. Journal of Public Economics, 70, 37-51. https://doi.org/10.1016/S0047-2727(98)00059-0

Corneo, G., \& Jeanne, O. (1999). Social Organization in an Endogenous Growth Model. International Economic Review, 40, 711-726. https://doi.org/10.1111/1468-2354.00036

Diallo, M. F., Mouelhi, N. B. D., Gadekar, M., \& Schill, M. (2020). CSR Actions, Brand Value, and Willingness to Pay a Premium Price for Luxury Brands: Does Long-Term Orientation Matter? Journal of Business Ethics, 169, 241-260. https://doi.org/10.1007/s10551-020-04486-5

Eckhardt, G. M., Belk, R. W., \& Wilson, J. A. J. (2015). The Rise of Inconspicuous Consumption. Journal of Marketing Management, 31, 807-826. https://doi.org/10.1080/0267257X.2014.989890

Furnham, A., \& Valgeirsson, H. (2007). The Effect of Life Values and Materialism on Buying Counterfeit Products. The Journal of Socio-Economics, 36, 677-685. https://doi.org/10.1016/j.socec.2007.01.004

Goenka, S., \& Thomas, M. (2020). The Malleable Morality of Conspicuous Consumption. Journal of Personality and Social Psychology, 118, 562-583. https://doi.org/10.1037/pspp0000237

Goldsmith, R. E., \& Clark, R. A. (2012). Materialism, Status Consumption, and Consumer Independence. The Journal of Social Psychology, 152, 43-60. https://doi.org/10.1080/00224545.2011.555434

Greenberg, D., Ehrensperger, E., Schulte-Mecklenbeck, M., Hoyer, W. D., Zhang, Z. J., \& Krohmer, H. (2020). The Role of Brand Prominence and Extravagance of Product Design in Luxury Brand Building: What Drives Consumers' Preferences for Loud versus Quiet Luxury? Journal of Brand Management, 27, 195-210.

https://doi.org/10.1057/s41262-019-00175-5

Grossman, P. (2011). Defining Mindfulness by How Poorly I Think I Pay Attention during Everyday Awareness and Other Intractable Problems for Psychology's (Re)Invention of Mindfulness: Comment on Brown et al. (2011). Psychological Assessment, 23, 1034-1040. https://doi.org/10.1037/a0022713

Guiot, D., \& Roux, D. (2010). A Second-Hand Shoppers' Motivation Scale: Antecedents, Consequences, and Implications for Retailers. Journal of Retailing, 86, 355-371. https://doi.org/10.1016/j.jretai.2010.08.002

Heffetz, O. (2012). Who Sees What? Demographics and the Visibility of Consumer Ex- 
penditures. Journal of Economic Psychology, 33, 801-818.

https://doi.org/10.1016/j.joep.2012.02.005

Huh, K. (2014). The Effects of Consumers' Ethics and Consumers' Attitude for Counterfeit Products on Consumers' Purchase Behavior of Counterfeit Products. Journal of Consumer Studies, 25, 63-84.

Jaikumar, S., \& Sarin, A. (2015). Conspicuous Consumption and Income Inequality in an Emerging Economy: Evidence from India. Marketing Letters, 26, 279-292. https://doi.org/10.1007/s11002-015-9350-5

Jaikumar, S., Singh, R., \& Sarin, A. (2018). "I Show Off, So I Am Well Off”: Subjective Economic Well-Being and Conspicuous Consumption in an Emerging Economy. Journal of Business Research, 86, 386-393. https://doi.org/10.1016/j.jbusres.2017.05.027

Jeong, K.-H., \& Jeon, I.-K. (2020). The Effect of Golf Participants of Social Face Sensitivity on Symbolic Consumption and Conspicuous Consumption. Journal of Golf Studies, 14, 49-65. https://doi.org/10.34283/ksgs.2020.14.1.5

Jhamb, D., Aggarwal, A., Mittal, A., \& Paul, J. (2020). Experience and Attitude towards Luxury Brands Consumption in an Emerging Market. European Business Review, 32, 909-936. https://doi.org/10.1108/EBR-09-2019-0218

Joncourt, S., Gebauer, H., Reynoso, J., Cabrera, K., Valdés, A., \& Greve, K. (2019). Extending the Base-of-the-Pyramid Concept. Service Science, 11, 241-261. https://doi.org/10.1287/serv.2019.0247

Kahle, L. R., Shoham, A., Rose, G., Smith, M., \& Batra, R. (2003). Economic versus Personal Future-Oriented Attitudes as Consumer Shopping Indicators. Journal of Euromarketing, 12, 35-54. https://doi.org/10.1300/J037v12n03 04

Kamakura, W. A., \& Du, R. Y. (2012). How Economic Contractions and Expansions Affect Expenditure Patterns. Journal of Consumer Research, 39, 229-247.

https://doi.org/10.1086/662611

Kapeller, J., \& Schuetz, B. (2015). Conspicuous Consumption, Inequality and Debt: The Nature of Consumption-Driven Profit-Led Regimes. Metroeconomica, 66, 51-70. https://doi.org/10.1111/meca.12061

Kapferer, J.-N., \& Michaut-Denizeau, A. (2014). Is Luxury Compatible with Sustainability? Luxury Consumers' Viewpoint. Journal of Brand Management, 21, 1-22. https://doi.org/10.1057/bm.2013.19

Kaufman, B. E. (2018). How Capitalism Endogenously Creates Rising Income Inequality and Economic Crisis: The Macro Political Economy Model of Early Industrial Relations. Industrial Relations: A Journal of Economy and Society, 57, 131-173. https://doi.org/10.1111/irel.12201

Keinan, A., Bellezza, S., \& Paharia, N. (2019). The Symbolic Value of Time. Current Opinion in Psychology, 26, 58-61. https://doi.org/10.1016/j.copsyc.2018.05.001

Kessous, A., \& Valette-Florence, P. (2019). "From Prada to Nada": Consumers and Their Luxury Products: A Contrast Between Second-Hand and First-Hand Luxury Products. Journal of Business Research, 102, 313-327. https://doi.org/10.1016/j.jbusres.2019.02.033

Kim, J.-E., Lloyd, S., Adebeshin, K., \& Kang, J.-Y. M. (2019). Decoding Fashion Advertising Symbolism in Masstige and Luxury Brands. Journal of Fashion Marketing and Management, 23, 277-295. https://doi.org/10.1108/JFMM-04-2018-0047

Kistruck, G. M., Sutter, C. J., Lount Jr., R. B., \& Smith, B. R. (2013). Mitigating Principal-Agent Problems in Base-of-the-Pyramid Markets: An Identity Spillover Perspective. Academy of Management Journal, 56, 659-682. https://doi.org/10.5465/amj.2011.0336 
Klabi, F. (2020). To What Extent Do Conspicuous Consumption and Status Consumption Reinforce the Effect of Self-Image Congruence on Emotional Brand Attachment? Evidence from the Kingdom of Saudi Arabia. Journal of Marketing Analytics, 8, 99-117. https://doi.org/10.1057/s41270-020-00073-9

Kwon, Y. (2020). Exploring the Mediating Effect of Conspicuous Consumption by Utilizing Mobile Phone Brands. Journal of Distribution Science, 18, 15-24.

Lai, C. S. Y., Hui, P. C. L., \& Ng, F. S. F. (2019). Promoting Quality of Life through Fashion for Function and Design. In D. T. L. Shek, G. Ngai, \& S. C. F. Chan (Eds.), Service-Learning for Youth Leadership: Quality of Life in Asia (pp. 185-198). Singapore: Springer. https://doi.org/10.1007/978-981-13-0448-4 11

Latter, C., Phau, I., \& Marchegiani, C. (2010). The Roles of Consumers Need for Uniqueness and Status Consumption in Haute Couture Luxury Brands. Journal of Global Fashion Marketing, 1, 206-214. https://doi.org/10.1080/20932685.2010.10593072

Liberman, J., Blecher, E., Carbajales, A. R., \& Burke, F. (2011). Opportunities and Risks of the Proposed FCTC Protocol on Illicit Trade. Tobacco Control, 20, 436-438.

Linssen, R., Van Kempen, L., \& Kraaykamp, G. (2011). Subjective Well-Being in Rural India: The Curse of Conspicuous Consumption. Social Indicators Research, 101, 57-72. https://doi.org/10.1007/s11205-010-9635-2

Mann, B. J. S., \& Sahni, S. K. (2015). Exploring the Drivers of Status Consumption for the Wedding Occasion. International Journal of Market Research, 57, 179-202. https://doi.org/10.2501/IJMR-2015-017

Matos, C. (2019). Inequality and Crisis: Conspicuous Consumption as the Missing Link in the Portuguese Case. Journal of Economic Issues, 53, 26-38. https://doi.org/10.1080/00213624.2019.1556999

Mostafa, M. M. (2019). Profiling Kuwaiti Female Apparel Consumers Self-Identity, Social Interactions, and Prestige Consumption. International Journal of Sociology and Social Policy, 39, 98-117. https://doi.org/10.1108/I]SSP-06-2018-0109

Mullainathan, S. (2012). Psychology and Development Economics. In P. Diamond, \& H. Vartiainen (Eds.), Behavioral Economics and Its Applications (pp. 85-114). Princeton, NJ: Princeton University Press. https://doi.org/10.2307/j.ctvd58v0s.7

Mumel, D., \& Snoj, B. (1999). How Does the Evaluation of Visibility and Necessity of Product Use Indicate the Scope of Influence of Reference Groups on the Choice of Product and Its Brand Name? der markt, 38, 155-166.

https://doi.org/10.1007/BF03036333

Nabi, N., O'Cass, A., \& Siahtiri, V. (2019a). Status Consumption in Newly Emerging Countries: The Influence of Personality Traits and the Mediating Role of Motivation to Consume Conspicuously. Journal of Retailing and Consumer Services, 46, 173-178. https://doi.org/10.1016/j.jretconser.2017.09.009

Nabi, N., Siahtiri, V., \& O’Cass, A. (2019b). In Search of Status: Unpacking the Relationship of Status with Individualism-Collectivism, Counterconformity Motivations and Life Satisfaction. Journal of Retailing and Consumer Services, 51, 378-386. https://doi.org/10.1016/j.jretconser.2019.07.005

Neave, L., Tzemou, E., \& Fastoso, F. (2020). Seeking Attention versus Seeking Approval: How Conspicuous Consumption Differs between Grandiose and Vulnerable Narcissists. Psychology \& Marketing, 37, 418-427. https://doi.org/10.1002/mar.21308

Ochkovskaya, M. (2016). Chandler's Effect in Luxury Brands Consumption. Proceedings of the 1st International Conference Contemporary Issues in Theory and Practice of Management CITPM 2016, Czestochowa, Poland, 21-22 April 2016. 
Oe, H., Sunpakit, P., Yamaoka, Y., \& Liang, Y. (2018). An Exploratory Study of Thai Consumers' Perceptions of "Conspicuousness": A Case of Luxury Handbags. Journal of Consumer Marketing, 35, 601-612. https://doi.org/10.1108/JCM-01-2017-2058

Olukoju, A. (2018). "Filthy Rich" and "Dirt Poor": Social and Cultural Dimensions of Solid Waste Management (SWM) in Lagos. Social Dynamics: A Journal of African Studies, 44, 88-106. https://doi.org/10.1080/02533952.2018.1430475

Perez-Truglia, R. (2013). A Test of the Conspicuous-Consumption Model Using Subjective Well-Being Data. Journal of Socio-Economics, 45, 146-154.

https://doi.org/10.1016/j.socec.2013.05.012

Pine, B., \& Gilmore, J. (2013). The Experience Economy: Past, Present and Future. In J. Sundbo, \& F. Sørensen (Eds.), Handbook on the Experience Economy (pp. 21-44). Cheltenham: Edward Elgar Publishing.

Piotrowska, M. (2017). The Impact of Consumer Behavior on Financial Security of Households in Poland. Contaduría y Administración, 62, 461-504. https://doi.org/10.1016/j.cya.2017.02.001

Poddar, A., Foreman, J., Banerjee, S. S., \& Ellen, P. S. (2012). Exploring the Robin Hood Effect: Moral Profiteering Motives for Purchasing Counterfeit Products. Journal of Business Research, 65, 1500-1506. https://doi.org/10.1016/j.jbusres.2011.10.017

Qattan, J., \& Al Khasawneh, M. (2020). The Psychological Motivations of Online Conspicuous Consumption: A Qualitative Study. International Journal of E-Business Research, 16, 1-16. https://doi.org/10.4018/IJEBR.2020040101

Quach, S., \& Thaichon, P. (2018). Dark Motives-Counterfeit Selling Framework: An Investigate on the Supply Side of the Non-Deceptive Market. Marketing Intelligence \& Planning, 36, 245-259. https://doi.org/10.1108/MIP-04-2017-0069

Roux, D., \& Guiot, D. (2008). Measuring Second-Hand Shopping Motives, Antecedents and Consequences. Recherche et Applications en Marketing (English Edition), 23, 63-91. https://doi.org/10.1177/205157070802300404

Rucker, D. D., \& Galinsky, A. D. (2009). Conspicuous Consumption versus Utilitarian Ideals: How Different Levels of Power Shape Consumer Behavior. Journal of Experimental Social Psychology, 45, 549-555. https://doi.org/10.1016/j.jesp.2009.01.005

Sen, A. (1983). Poor, Relatively Speaking. Oxford Economic Papers, 35, 153-169. https://doi.org/10.1093/oxfordjournals.oep.a041587

Shaikh, S. (2019). The Malleable Self-Concept-Relationships between Young Adolescents' Self-Concept and Bandwagon Luxury Consumption. Journal of Marketing Development and Competitiveness, 13, 33-44. https://doi.org/10.33423/jmdc.v13i5.2640

Shukla, P. (2010). Status Consumption in Cross-National Context: Socio-Psychological, Brand and Situational Antecedents. International Marketing Review, 27, 108-129. https://doi.org/10.1108/02651331011020429

Simmel, G. (1957). Fashion. American Journal of Sociology, 62, 541-558. https://doi.org/10.1086/222102

Singh, R., \& Trott, S. (2019). Non-Deceptive Deliberate Purchase of Brand Lookalikes: A BOP Customer Value Perspective. Decision, 46, 15-26. https://doi.org/10.1007/s40622-019-0201-8

Sokolov, M., \& Sokolova, N. (2019). Do Low-Brow Tastes Demonstrate Stronger Categorical Differentiation? A Study of Fiction Readership in Russia. Poetics, 73, 84-99. https://doi.org/10.1016/j.poetic.2018.11.008

Sørensen, E. B., \& Hjalager, A.-M. (2020). Conspicuous Non-Consumption in Tourism: Non-Innovation or the Innovation of Nothing? Tourist Studies, 20, 222-247. 
https://doi.org/10.1177/1468797619894463

Srisomthavil, N., \& Assarut, N. (2018). The Impact of Perceived Counterfeit Luxury Brand Proliferation on Luxury Brand Values and Patronage Intention. Market-Tržište, 30, 41-60. https://doi.org/10.22598/mt/2018.30.1.41

Srivastava, A., Mukherjee, S., \& Jebarajakirthy, C. (2020). Aspirational Consumption at the Bottom of Pyramid: A Review of Literature and Future Research Directions. Journal of Business Research, 110, 246-259. https://doi.org/10.1016/j.jbusres.2019.12.045

Subrahmanyan, S., \& Gomez-Arias, J. T. (2008). Integrated Approach to Understanding Consumer Behavior at Bottom of Pyramid. Journal of Consumer Marketing, 25, 402-412. https://doi.org/10.1108/07363760810915617

Tade, O., \& Nnamani, M. A. (2017). Symbolic Status of Space: Event Centre Culture and Patronage in Nigeria. Journal of Asian and African Studies, 52, 646-656. https://doi.org/10.1177/0021909615605530

Tarola, O., \& Zanaj, S. (2019). Social Division in the Market: Conspicuous Consumption with Nationalist Feelings. Center for Research in Economic Analysis, University of Luxembourg, Luxembourg.

Tofighi, M., Grohmann, B., \& Bodur, H. O. (2020). Ethical Attribute and Brand Concept Congruity Enhances Brand Evaluations. European Journal of Marketing, 54, 79-108. https://doi.org/10.1108/EJM-02-2018-0104

Truong, Y., Mccoll, R., \& Kitchen, P. (2010). Uncovering the Relationships between Aspirations and Luxury Brand Preference. Journal of Product \& Brand Management, 19, 346-355. https://doi.org/10.1108/10610421011068586

Turunen, L. L. M., \& Leipamaa-Leskinen, H. (2015). Pre-Loved Luxury: Identifying the Meanings of Second-Hand Luxury Possessions. Journal of Product and Brand Management, 24, 57-65. https://doi.org/10.1108/JPBM-05-2014-0603

Turunen, L. L. M., \& Poyry, E. (2019). Shopping with the Resale Value in Mind: A Study on Second-Hand Luxury Consumers. International Journal of Consumer Studies, 43, 549-556. https://doi.org/10.1111/ijcs.12539

Van Boven, L. (2005). Experientialism, Materialism, and the Pursuit of Happiness. Review of General Psychology, 9, 132-142. https://doi.org/10.1037/1089-2680.9.2.132

Veblen, T. (1899). Mr. Cummings's Strictures on "The Theory of the Leisure Class". Journal of Political Economy, 8, 106-117. https://doi.org/10.1086/250640

Verdugo, G. B., \& Ponce, H. R. (2020). Gender Differences in Millennial Consumers of Latin America Associated with Conspicuous Consumption of New Luxury Goods. Global Business Review, published online. https://doi.org/10.1177/0972150920909002

Wai, L. K., \& Osman, S. (2019). The Influence of Self-Esteem in the Relationship of Social Media Usage and Conspicuous Consumption. International Journal of Academic Research in Business and Social Sciences, 9, 335-352. https://doi.org/10.6007/IJARBSS/v9-i2/5549

Wang, Y., \& Qiao, F. (2020). The Symbolic Meaning of Luxury-Lite Fashion Brands among Younger Chinese Consumers. Journal of Fashion Marketing and Management, 24, 83-98. https://doi.org/10.1108/JFMM-09-2019-0204

Wiedmann, K.-P., Hennigs, N., \& Klarmann, C. (2012). Luxury Consumption in the Trade-Off between Genuine and Counterfeit Goods: What Are the Consumers' Underlying Motives and Value-Based Drivers? Journal of Brand Management, 19, 544-566. https://doi.org/10.1057/bm.2012.10

Wong, N. Y., \& Ahuvia, A. C. (1998). Personal Taste and Family Face: Luxury Consump- 
tion in Confucian and Western Societies. Psychology \& Marketing, 15, 423-441. https://doi.org/10.1002/(SICI)1520-6793(199808)15:5<423::AID-MAR2>3.0.CO;2-9

Yarimoglu, E., \& Binboga, G. (2019). Understanding Sustainable Consumption in an Emerging Country: The Antecedents and Consequences of the Ecologically Conscious Consumer Behavior Model. Business Strategy and the Environment, 28, 642-651. https://doi.org/10.1002/bse.2270

Zhao, T., Jin, X., Xu, W., Zuo, X., \& Cui, H. (2017). Mating Goals Moderate Power's Effect on Conspicuous Consumption among Women. Evolutionary Psychology, 15. https://doi.org/10.1177/1474704917723912 